NBER WORKING PAPER SERIES

\title{
SERIAL DEFAULT AND THE "PARADOX" OF RICH TO POOR CAPITAL FLOWS
}

\author{
Carmen M. Reinhart \\ Kenneth S. Rogoff \\ Working Paper 10296 \\ http://www.nber.org/papers/w10296 \\ NATIONAL BUREAU OF ECONOMIC RESEARCH \\ 1050 Massachusetts Avenue \\ Cambridge, MA 02138 \\ February 2004
}

This paper was prepared for American Economic Review Papers and Proceedings. Reinhart: Department of Economics and School of Public Affairs, University of Maryland, College Park, 20431 (email:creinhar@umd.edu); Rogoff: Department of Economics, Harvard University, 231 Littauer, Cambridge, MA 02138 (e-mail: krogoff@harvard.edu). The authors wish to thank Vincent R. Reinhart and Miguel A. Savastano for helpful comments and suggestions and Kenichi Kashiwase and Stacia Joy Sowerby for excellent research assistance. The views expressed herein are those of the authors and not necessarily those of the National Bureau of Economic Research.

(C2004 by Carmen M. Reinhart and Kenneth S. Rogoff. All rights reserved. Short sections of text, not to exceed two paragraphs, may be quoted without explicit permission provided that full credit, including (C) notice, is given to the source. 
Serial Default and the "Paradox" of Rich to Poor Capital Flows

Carmen M. Reinhart and Kenneth S. Rogoff

NBER Working Paper No. 10296

February 2004

JEL No. F21, F32, F34

\section{$\underline{\text { ABSTRACT }}$}

Lucas (1990) argued that it was a paradox that more capital does not flow from rich countries to poor countries. He rejected the standard explanation of expropriation risk and argued that paucity of capital flows to poor countries must instead be rooted in externalities in human capital formation favoring further investment in already capital rich countries. In this paper, we review the various explanations offered for this "paradox." There is no doubt that there are many reasons why capital does not flow from rich to poor nations - yet the evidence we present suggests some explanations are more relevant than others. In particular, as long as the odds of non repayment are as high as 65 percent for some low income countries, credit risk seems like a far more compelling reason for the paucity of rich-poor capital flows. The true paradox may not be that too little capital flows from the wealthy to the poor nations, but that too much capital (especially debt) is channeled to "debt intolerant" serial defaulters.

Carmen M. Reinhart

University of Maryland

School of Public Affairs and Department of Economi

4105 Van Munching Hall

College Park, Maryland 20742

and NBER

creinhar@umd.edu

Kenneth S. Rogoff

Research Department, HQ10-700

International Monetary Fund

700 19th Street, NW

Washington, DC 20431

and NBER

krogoff@harvard.edu 


\section{INTRODUCTION}

Lightning may never strike twice in the same place, but the same cannot be said of sovereign default. Throughout history governments have demonstrated that "serial default" is the rule, not the exception. Argentina has famously defaulted on five occasions since its birth in the 1820s. However, as shown in Table 1, Argentina's record is surpassed by many countries in the New World (Brazil, Liberia, Mexico, and Uruguay, Venezuela and Ecuador) and by almost as many in the Old World (France, Germany, Portugal, Spain, and Turkey). ${ }^{1}$ At the same time, a smaller and dwindling number of developing countries such as India, Korea, Malaysia, Mauritius, Singapore, and Thailand have yet to default, despite being tested by severe turmoil, including the Asian crisis of the late 1990s. ${ }^{2}$ What can explain such striking differences in default performance? State-of -the-art theoretical models of debt crises stress the importance of multiple equilibria where random investor panics can become self-fulfilling. The implication is that economists may never be able to precisely explain sovereign defaults, much less

\footnotetext{
${ }^{1}$ Standard \& Poor's defines sovereign default as the failure of an obligor to meet a principal or interest payment on the due date (or within the specified grace period) contained in the original terms of the debt issue. A debt restructuring where the new debt contains less favorable terms than the original issue is also counted as default. For 1800 to the present, this is the definition of default used to construct Table 1.
}

2 Indonesia and Pakistan, with no prior history of default, joined the ranks of "defaulters" in the late 1990s. 
predict them. Nevertheless, the fact that sovereign defaults tend to recur like clockwork in some countries, while being absent in others, suggests that there must be a significant explainable component as well.

In this paper, we begin by briefly examining the history and incidence of serial default. We then review some of the explanations offered in the literature on the "paradox" of why capital does not flow from rich to poor countries and link this question to sovereigns' credit track records. There is no doubt that there are many reasons why capital does not flow from rich to poor nations and that some of these reasons are subtle, difficult to model, and even more difficult to quantify. Yet the evidence we present here, which draws heavily on the earlier work of Carmen M. Reinhart, Kenneth S. Rogoff, and Miguel A. Savastano (2003), suggests some explanations may be more relevant than others. In the end the true paradox may not be that too little capital flows from the wealthy to the poor nations, but that in uneven bouts and volatile cycles, too much capital (specifically in the form of debt) is channeled to "debt intolerant" serial defaulters.

Government and government-guaranteed external debt is typically, though not always, the main locus of problems. We offer some concluding reflections on what debt intolerance implies for safe debt thresholds in developing countries that are aspiring to graduate from their developing status.

\section{Serial Default in Historical Perspective}

Today's developing countries did not invent sovereign default nor did they invent serial default. As shown in Table 1, France and Germany have each defaulted eight times since 1500 (a factor one does not see emphasized in today's discussions of what a good 
match these countries are for a currency union). The Russia post-communist default of 1998 rocked the world, as did Russia's post-Tsarist default early in the twentieth century. But Russia's two famous defaults should not have come as a complete shock: The country had already defaulted twice previously. The all-time post-1500 record holder, however, appears to be Spain, which has clocked a remarkable 13 defaults.

Table 1. Selected Cases of Serial Default in The Old AND NeW "EMerging MARKETS": 1501-2002

\begin{tabular}{|c|c|c|c|c|}
\hline \multirow[t]{2}{*}{ Country } & \multicolumn{4}{|c|}{ Number of default (or restructuring) episodes } \\
\hline & $1501-1800$ & $1801-1900$ & $1901-2002$ & Total Number \\
\hline Spain & 6 & 7 & 0 & 13 \\
\hline Ecuador & n.a. & 3 & 6 & 9 \\
\hline Venezuela & n.a. & 5 & 4 & 9 \\
\hline France & 8 & n.a. & 0 & 8 \\
\hline Germany & 1 & 5 & 2 & 8 \\
\hline Mexico & n.a. & 5 & 3 & 8 \\
\hline Uruguay & n.a. & 2 & 6 & 8 \\
\hline Brazil & n.a. & 2 & 5 & 7 \\
\hline Colombia & n.a. & 4 & 3 & 7 \\
\hline Liberia & n.a. & 1 & 6 & 7 \\
\hline Peru & n.a. & 2 & 5 & 7 \\
\hline Turkey/Ottoman Empire & n.a. & 1 & 6 & 7 \\
\hline Portugal & 1 & 5 & 0 & 6 \\
\hline Argentina & n.a. & 2 & 3 & 5 \\
\hline Austria & n.a. & 5 & 4 & 5 \\
\hline Bulgaria & n.a. & 2 & 3 & 5 \\
\hline Greece & n.a. & 4 & 1 & 5 \\
\hline Yugoslavia (Former) & n.a. & 1 & 4 & 5 \\
\hline Chile & n.a. & 2 & 2 & 4 \\
\hline Russia & n.a. & 1 & 3 & 4 \\
\hline Poland & n.a. & n.a. & 3 & 3 \\
\hline China & n.a. & n.a. & 2 & 2 \\
\hline Egypt & n.a. & 1 & 1 & 2 \\
\hline
\end{tabular}

Sources: Reinhart, Rogoff, and Savastano (2003) and sources cited therein and Standard and Poor's Credit Week, various issues. 
Reinhart, Rogoff and Savastano (2003) find that a country's history of default on external debt, together with its inflation history (which effectively proxies for a government's record of real repayment on internal obligations), provides a good measure of a country's capacity to bear debt without brooking high risk of default. They find that countries can graduate from being serial defaulters as, say, Greece did in recent decades. ${ }^{3}$ The process of "graduation", however, is seldom accomplished in a short time frame. Default exacerbates weak political institutions, laying the seeds for further defaults later down the road. Their evidence also suggests that the first default may be much more costly than later ones. Thus, whereas countries may go to great lengths to avoid a first or perhaps second default, serial defaulters — who have less of a reputation to lose — face a different calculus. To graduate to developed-country status, serial defaulters' main concern should be in achieving and sustaining markedly lower debt burdens, a transition that is seldom accomplished solely through high growth and debt repayments. Nevertheless, it is notable that one-time serial defaulter Chile, is showing early signs of having "graduated" in no small part by steadily reducing external debt from 134 percent of GNP in 1985 to about of 30 percent twelve years later. This sharply contrasts the external debt ratios of 50 percent (or higher) for many of the serial defaulters shown in Table 1 .

\footnotetext{
${ }^{3}$ Greece's foreign currency bond debt was in default status until 1964.
} 


\section{Rich to Poor Capital Flows: Alternative Explanations}

It is interesting to use the evidence on serial default to re-examine a broader debate in the growth literature on why countries do not seem to converge more rapidly in per capita income. In a much-cited paper presented at the American Economic Association meetings a decade and half ago, Robert Lucas (1990) argued that it was a puzzle that more capital does not flow from rich countries to poor countries, given back of the envelope calculations suggesting massive differences in physical rates of return in favor of capitalpoor countries. Lucas rejected the standard explanation of expropriation risk, pointing to the fact that before World War II many of today's developing countries were colonies and subject to rich-country laws. He argued that paucity of capital flows to poor countries must instead be rooted in more fundamental economic forces, such as externalities in human capital formation favoring further investment in already capital rich countries.

Lucas "new growth theory" explanation stands in interesting contrast to other theories of the same phenomenon, generally emphasizing credit market imperfections. These include the seminal reputation and debt model of Jonathan Eaton and Mark Gersovitz (1981), the legal sanctions based bargaining framework of Jeremy Bulow and Rogoff (1989), and the domestic institutions based framework of Laura Alfaro, Sebnem Kalemli-Ozcan, and Vadym Volosovych (2003). These alternative explanations (which can be interpreted as variants of expropriation risk) rely on weak contract enforcement preventing the full blossoming of international capital markets needed to accommodate financial flows that, otherwise, would go to developing countries with higher marginal products of capital. Somewhere in between these explanations and the human capital 
externalities model of Lucas is the framework advanced in Mark Gertler and Rogoff (1989, 1990). Gertler and Rogoff show that even where lending contracts can be enforced perfectly across borders, regions with higher wealth will suffer less from innate credit market imperfections thanks to the ability of entrepreneurs to rely more on self-finance. Gertler and Rogoff illustrate how, in principle, it is possible for these endogenously determined credit market imperfections to cause net capital flows to go from poor to rich, even with identical technologies and identical institutions for contract enforcement.

\section{EVIDENCE}

What is the evidence on these alternative views? Lucas dismisses the political risk factor using the example India. Prior to 1945, India was subject to British rule, and yet capital labor ratios in India remained far below that of Britain. For the colonial period, one answer might be that the penetration of British law and institutions into distant India might have been far from perfect, with local culture and customs playing a large role. So British investors by no means regarded an investment in rural India to be as easy to monitor or enforce as an investment in land south of London. Moreover, the record of rebellion while a British colony probably implied that the ex ante risk of expropriation was greater than the ex post one. (Perhaps an even more obvious example would be colonial Ireland, which would not have presented itself as a particularly attractive investment opportunity given its many rebellions). Post independence, India chose a very autarkic development strategy until the 1990s, sharply limiting the inflow of foreign goods and capital. To date, a myriad of capital controls remain firmly in place. 
It is plausible, of course, that even if political risk does compromise the rights of both external and internal creditors, rates of return differentials may be so large as to swamp this concern, and funds would still flow in large quantities from rich to poor countries. We do not take up this issue here, though a growing literature points to a number of factors, other than human capital externalities, that would mute return differentials. One simple point is that in a multi-good world, trade in commodities will tend to reduce differences in rates of return to capital and potentially even eliminate them; this is simply Samuelson's classic factor price equalization theorem (see Maurice Obstfeld and Rogoff, 1996 among others. Also, as Gourinchas and Jeanne (2003) recently quantify, domestic institutional factors may swamp differences in capital-labor ratios in explaining cross-country output per capita differentials in an extended Solow model. Human capital externalities may also be important but the positive evidence that they are central in explaining cross-country income differentials seems scant (see, e.g., Helpman, 2004).

There is arguably more positive evidence in favor of the poor-rich capital flow model of Gertler-Rogoff. Figure 1 shows that private lending to developing countries rises more than percent for percent with per capita income among poor developing countries, a prediction of their model corroborated by Philip Lane (2003) who attempts to deal with exogeneity issues by using standard cross-section growth variables to proxy for physical rates of return. 


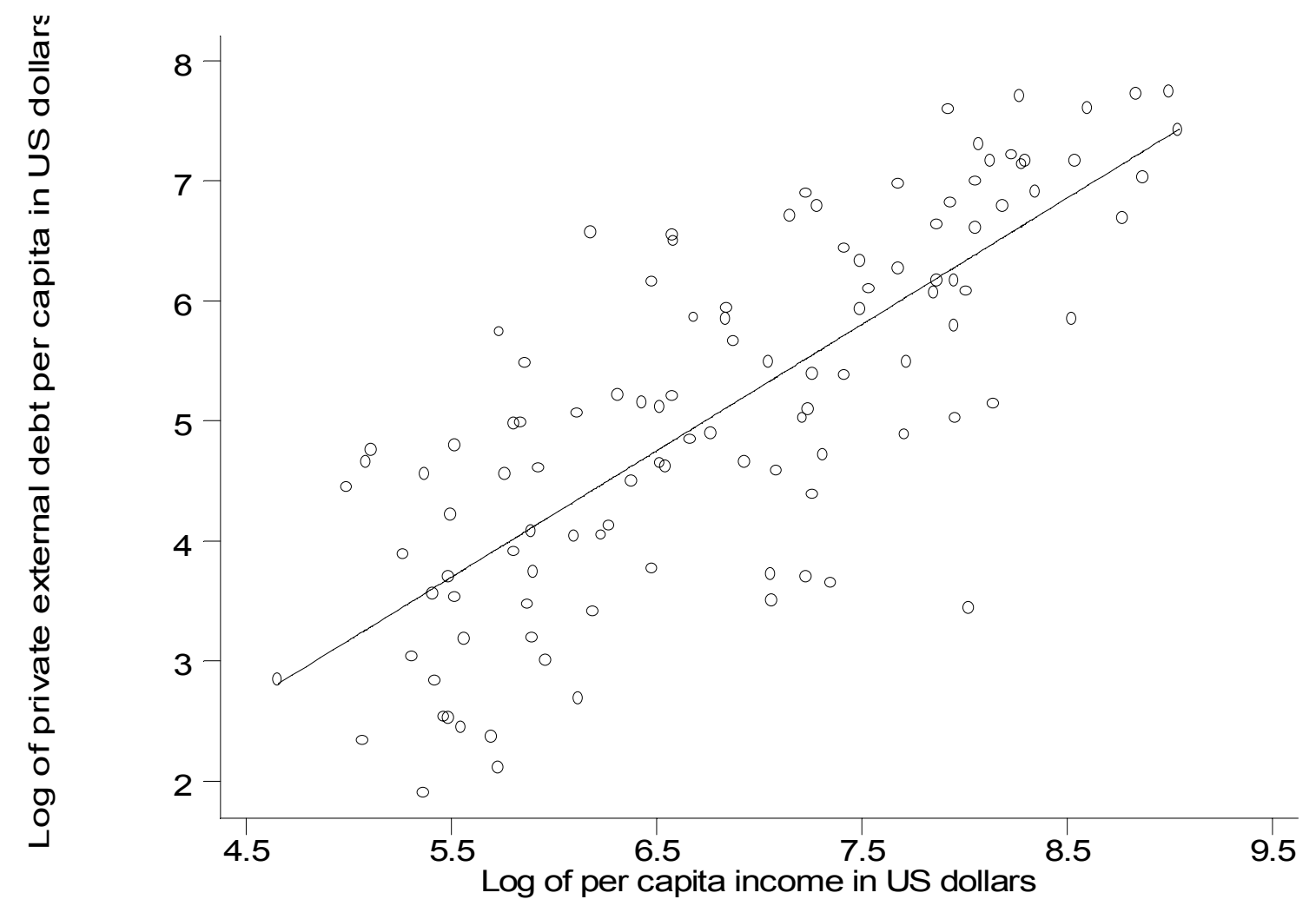

Figure 1. Private External Debt and Income: 1990-1999

Source: Global Development Finance, the World Bank, various issues.

In our view, however, there is much more evidence in pointing to the primal role of political and credit market risk. For example, Alfaro (et. al.) present evidence for equity and direct foreign investment that parallels that shown for private lending in Figure 1. Extending Lane, their cross-country regressions suggest that the principle driving factor is differences in the quality of institutions, including prevalence of corruption. As Table 2 illustrates, only 12 percent of low income countries issued any equity at all during 19832003 , and only a third of middle income countries did so - a contrast to the fact that all the OECD countries issued equity. Indeed, the high-income countries accounted for 90 percent 
of the value of all equities issued in that period. Given the high risk faced by developing countries due to factors such as volatile weather and commodity prices--and therefore the huge potential gains to diversification-this fact is hardly consistent with the notion that institutions and enforcement technologies are not a problem. Indeed, outside the roughly 25 "emerging markets" that account for the bulk of financial flows from the rich, the remaining developing countries receive funds mainly through aid and direct foreign investment, the latter typically being the most difficult to expropriate due to the importance of foreign investor technology.

TABLE 2. GROSS INTERNATIONAL EQUITY ISSUES BY INCOME LEVEL: TOTALS, 1983-2003

\begin{tabular}{|c|c|c|c|c|c|c|}
\hline & \multirow[t]{3}{*}{ Low } & \multicolumn{3}{|c|}{ Middle to: } & \multicolumn{2}{|c|}{ High } \\
\hline & & \multicolumn{2}{|c|}{ Low } & \multirow[t]{2}{*}{ High } & \multirow[t]{2}{*}{ Total } & \multirow[t]{2}{*}{ OECD } \\
\hline & & Total & ex. China & & & \\
\hline \multicolumn{7}{|c|}{ Bank of International Settlements } \\
\hline Billions of US dollars & 19.5 & 89.5 & 33.4 & 40.1 & $1,314.3$ & $1,215.4$ \\
\hline Percent of total issued & 1.3 & 6.1 & 2.3 & 2.8 & 89.8 & 83.1 \\
\hline Percent of countries issuing equities & 4.5 & 19.2 & & 15.4 & 55.4 & 100 \\
\hline \multicolumn{7}{|c|}{ Bank of International Settlements-Dealogic Data ${ }^{1}$} \\
\hline \multirow{2}{*}{$\begin{array}{l}\text { Percent of countries issuing equities } \\
\text { Number of countries in income categories }\end{array}$} & 12.1 & 34.6 & & 38.5 & 60.7 & 100 \\
\hline & 66 & 52 & & 39 & 56 & 24 \\
\hline \multicolumn{7}{|c|}{$\begin{array}{l}\text { Sources: Bank of International Settlements, Table 18. Announced International Equity Issues by Nationality of User, } \\
\text { Dealogic, and World Bank, Global Development Finance, authors' calculations. } \\
\text { Notes: The classification of countries by level of income is taken from the World Bank. } \\
1 \text { The more comprehensive pooled data uses the Bank of International Settlements (BIS) data for those reported by the } \\
\text { BIS and Dealogic data for all other countries. The dollar figures and its distribution across income groups is only } \\
\text { marginally affected when countries covered by Dealogic but not by the BIS are included in the totals, as the former is } \\
\text { only adding the smaller issues. }\end{array}$} \\
\hline
\end{tabular}

Perhaps the most compelling evidence that credit markets are the central problem, however, comes from returning to our theme of serial default. Figure 2 plots per capita income (1998-2002 average) on the horizontal axis versus percentage of total years in default since 1946 (or since independence, whichever comes later), on the vertical axis. As 
the figure illustrates, there is a remarkable correlation, with the poorest countries often in default one-third to one-half the time despite having borrowed very little; many African countries fit this mold, for example. As Table 3 shows, the data neatly fit a logistic curve. ${ }^{4}$ No wonder flows are so small!

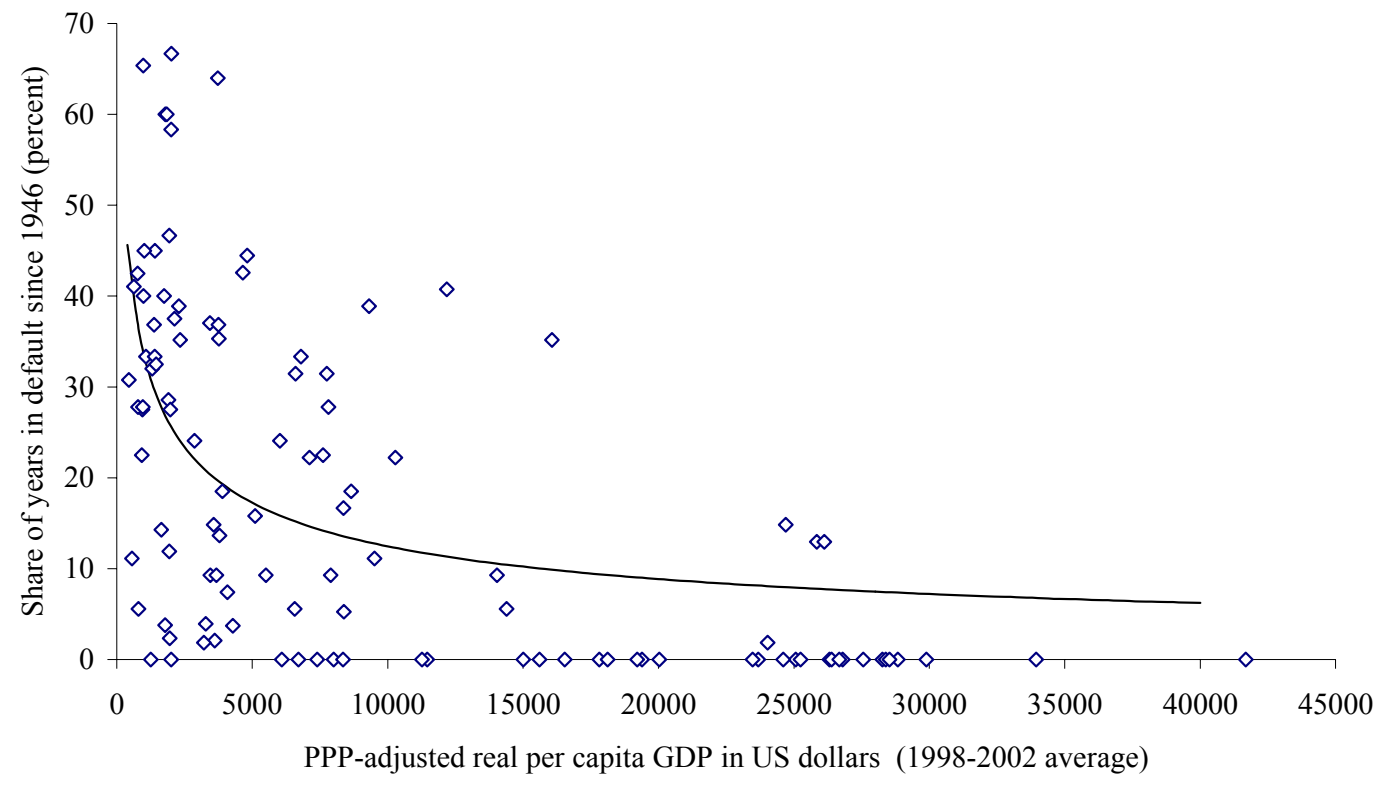

Figure 2. Share of Years in Default and Income Levels

Sources: World Economic Outlook, International Monetary Fund, various issues, Reinhart, Rogoff, and Savastano (2003) and sources cited therein.

Notes: If the country gained its independence after 1946, we calculate the shares for the post independence period.

\footnotetext{
${ }^{4}$ The logistic function is an obvious choice given that the dependent variable (share of years in default) is bounded between zero and one and that theoretical models stress multiple equilibria and significant nonlinearities.
} 


\section{TABle 3 The InCOME AND DEFAUlT LINK: CROSS-SECTION EVIDENCE}

\begin{tabular}{|c|c|c|c|c|}
\hline \multicolumn{5}{|c|}{$\begin{array}{l}\text { The standard logistic distribution is given by: } \\
Y_{\mathrm{i}}=1 /\left[1+e^{(\alpha+\beta \mathrm{Xi})}\right] \text {, where: } \\
\mathrm{Y}_{\mathrm{i}}=\text { share of years in a default (or restructuring) state since } 1946 \text { or since year of independence, if subsequent to } 1946 . \\
\mathrm{X}_{\mathrm{i}}=\log \text { of PPP adjusted real per capita GDP in US dollars. } \\
\alpha \text { and } \beta \text { are constants and } \beta>0 \text { is the prior. }\end{array}$} \\
\hline \multirow{2}{*}{\multicolumn{5}{|c|}{$\begin{array}{c}\text { Number of } \\
\text { bservations }=106 \\
\mathrm{R}^{2}=0.32\end{array}$}} \\
\hline & & & & \\
\hline$\beta$ & 0.55 & 5.66 & 0.00 & $\mathrm{DW}=1.81$ \\
\hline
\end{tabular}

Sources: International Monetary Fund, World Economic Outlook, Reinhart, Rogoff, and Savastano (2003) and sources cited therein and Standard and Poor's Credit Week, various issues, and authors' calculations.

Notes: The regression line and actual observations are plotted in Figure 2.

Thus the key explanation to the "paradox" of why so little capital flows to poor countries may be quite simple--countries that do not repay their debts have a relatively difficult time borrowing from the rest of the world. The fact that so many poor countries are in default on their debts, that so little funds are channeled through equity, and that overall private lending rises more than proportionally with wealth, all strongly support the view that credit markets and political risk are the main reasons why we do not see more capital flows to developing countries. If credit market imperfections abate over time due to better institutions, human capital externalities or other "new growth" elements may come to play a larger role. But as long as the odds of non repayment are as high as 65 percent for some low income countries, credit risk seems like a far more compelling reason for the paucity of rich-poor capital flows.

\section{POLICY IMPLICATIONS}

We have argued here (as in Reinhart, Rogoff and Savastano, 2003) that the pervasive phenomenon of serial default, and the costs such defaults entail, suggests that emerging market countries may need to aim for far lower levels of external debt-to-GDP 
than what has been conventionally considered prudent. Indeed, prudent external debt thresholds may be closer to 15 to 30 percent (the level seen in several of the emerging non defaulters) than the much higher levels today one sees in countries with a history of serial default, such as Turkey and Brazil. As far as emerging markets are concerned, comparisons to the lofty debt ratios some wealthy countries carry are irrelevant and governments in developing countries who disregard this difference in debt tolerance are only likely to propagate the serial default syndrome. Indeed, if anything net external debt thresholds may have to become more conservative to accommodate the sharp rise seen in many countries' domestic public debt. For instance, domestic government debt as a percent of GDP in India, Korea, and Thailand was in single digits in the early 1980s and by the late 1990 s it had risen to 86,63 , and 76 percent, respectively, making these countries' reserve accumulation more understandable.

There is also a case for having rich countries make it more difficult, not less, to enforce sovereign debt contracts in rich-country courts, as Bulow and Rogoff (1990) and Rogoff (1999) suggest; see also Andrei Shliefer (2003). Though this would almost certainly reduce debt flows to many countries in the short run, it would lead to a strengthening of the international financial system in the long run, reducing reliance on debt and helping support the evolution of greater flows in equity and direct foreign investment.

In sum, the remarkable history of serial default suggests that there is no puzzle as to why capital does not flow in greater quantities from rich to poor. Rather, the real problem is how to prevent too much capital from flowing to serial defaulters - and especially their governments-- before they have "graduated" out of that state. 


\section{REFERENCES}

Alfaro, Laura, Kalemli-Ozcan, Sebnem, and Volosovych, Vadym. "Why Doesn't Capital Flow from Rich to Poor Countries? An Empirical Investigation." Mimeo, Harvard University, 2003.

Bulow, Jeremy, and Rogoff, Kenneth S. "A Constant Recontracting Model of Sovereign Debt," Journal of Political Economy, February 1989, 97, pp. 155-178.

Bulow, Jeremy, and Rogoff, Kenneth S. "Cleaning Up Third-World Debt Without Getting Taken to the Cleaners," Journal of Economic Perspectives, Winter 1990, 4, pp.31-42.

Eaton, Jonathan, and Gersovitz, Mark. "Debt with Potential Repudiation: Theoretical and Empirical Analysis, Review of Economic Studies, 1981, 48, pp. 289-309.

Gertler, Mark and Rogoff, Kenneth S. "Developing Country Borrowing and Domestic Wealth." National Bureau of Economic Research (Cambridge, MA) Working Paper No. 2887, March 1989.

Gourinchas, Pierre Olivier and Jeanne, Olivier. "The Elusive Benefits from Financial Market Integration.” Mimeo, International Monetary Fund, 2003.

Gertler, Mark, and Rogoff, Kenneth S. "North-South Lending and Endogenous Domestic Capital Market Inefficiencies." Journal of Monetary Economics, October 1990, 26, pp. 245-266.

Helpman, Elhanan. The Mystery of Economic Growth. Cambridge: Harvard University Press, forthcoming.

Lane, Philip. "Empirical Perspectives on Long-Term External Debt.” Mimeo, Trinity College, 2003.

Lucas, Robert. "Why Doesn't Capital Flow from Rich to Poor Countries? American Economic Review, May 1990 (Papers and Proceedings), 무, pp.92-96.

Obstfeld, Maurice and Rogoff, Kenneth S. Foundations of International Macroecononomics. Cambridge: MIT Press, 1996.

Reinhart, Carmen M., Rogoff, Kenneth S., and Savastano, Miguel A. "Debt Intolerance" Brookings Papers on Economic Activity, Spring 2003, 1, pp. 1-74.

Rogoff, Kenneth S. "Institutions for Reducing Global Financial Instability," Journal of Economic Perspectives, Fall 1999, 13, pp. 21-42.

Shliefer, Andrei. "Will the Sovereign Debt Market Survive?" American Economic Review May 2003, (Papers and Proceedings), 93. pp. 85-90. 